\title{
E-Learning-mediated Instruction: Preparing Innovative and Work Ready English Materials for Nursing Assistant Students
}

\author{
Made Hery Santosa ${ }^{1}$, Eva Agustino \\ Universitas Pendidikan Ganesha, Indonesia ${ }^{1,2}$ \\ Email: mhsantosa@ undiksha.ac.id ${ }^{1^{*}}$ \\ Email: evaagustino60@gmail.com²
}

\begin{abstract}
This study aimed at developing e-learning-based English materials for Nursing Assistant students by employing Lee and Owen's R\&D design model. The R\&D model consists of need analysis, design, and development. The need analysis was conducted in a vocational school in North Bali, Indonesia, to gather suitable information from the stakeholders. The data were from observation, recording, interview, and expert judgment analyzed both qualitatively and quantitatively. Results showed that Nursing assistant students needed specific English materials related to their future jobs. The designed materials comprised five units: General Assessment, Handling Patients, Patient's Hygiene, Checking Vital Signs, and Dimensions of Symptom. Using the criteria of good ESP material and good e-learning material, the developed materials are found to be in the excellent category. The study shows that Nursing assistant students need innovative and work-relevant materials. It is highly recommended to be utilized in the teaching and learning process.
\end{abstract}

Keywords: E-learning, English Material, ESP, Nursing assistants, R\&D.

\section{INTRODUCTION}

ASEAN Economic Community (AEC) emphasizes the integration of the global economy. It means that the ASEAN people should be ready to compete because everyone has the same opportunity to work in another country in a certain field (Kivunja, 2015; Umezaki, 2012). As English has been an international language, it is seen that the students' English proficiency should be of the standards required in the regional area. As one of the subject matters, English is taken by all senior high school and vocational high school students in Indonesia. The vocational schools prepare students to be ready for a real work field, be skillful based on their chosen major, and possess good English proficiency because they may work in another country or deal with a foreign customer.

Indonesia's English Proficiency Index (EPI) is reported to be at a low level number 74 from 100 countries) (Education First, 2020). This situation is not parallel to the government's $21^{\text {st }}$ learning century standards to equip graduates with life and career skills, learning, and innovation skills which cover 4C (critical 
thinking, communication, collaboration, and creativity) (Santosa, 2019), information, media and technology skills (Alismail \& McGuire, 2015). Thus, the English proficiency of the country must be improved to be able to compete for AEC.

As the school institutions are demanded to produce qualified human resources who can compete with ASEAN employment, in a specific field, like Nursing, graduates ready to face the global economy must be prepared. The focus of preparing graduates with English as one skill for the work-ready initiative on a specific field, as in the Nursing area, is in line with what the Indonesian Board of National Education Standard or Badan Standar Nasional Pendidikan (BNSP) (2006) stated that vocational education aims to improve intelligence, knowledge, personality, character, and skills of students for independent living and follow further education following the vocational program.

In a more familiar term, this focuses on English as a Specific Purpose (ESP). Hutchinson and Waters (1987) stated that ESP is an approach to language teaching in which all decisions as to content and method are based on the learner's reason for learning. The students learn the language to communicate a set of professional skills and perform particular jobrelated functions.

Moreover, a preliminary interview was conducted in Bali, Indonesia, in the real context of a vocational high school. Open-ended questions on the use of materials and foci of English learning in a specific context like Nursing assistant were proposed. The interview with the students showed that teachers still utilized general English materials in Nursing assistant classes. Teachers also admitted that they need specific materials for the subject. A further check on the existing document at the school supported the initial findings. The materials employed in the teaching and learning process emphasized teaching the Nursing assistant students more on General English with vocabulary and language functions rather than the specific-related materials to the learned subject.

Today's teaching and learning have been largely impacted by the development of Information and Communication Technology (ICT), modernization, and globalization. Nowadays, students are millennials and generation $\mathrm{Z}$ who learn differently from their teachers. They are multitaskers. They can use the Internet and mobile phone as a device to look for any information they need. ICT integration enables them to search for articles or information to accomplish any assignments given by the teachers. Lowerison et al. (2006) stated that technology has big potentials to change or transform the learning environment in terms of its atmosphere from passive learning into an active one.

E-Learning is one of the potential platforms that can be integrated into today's learning. It is a learning process done through online learning in which it is different from conventional teaching that focuses on the textbook (Condruz-bacescu, 2014). According to Vanve et al. (2016), E-learning also offers students control over the content, learning pace, and time. It allows students to tailor their experience to meet their learning objectives.

Following the suitable material and specific needs of the vocational students and the changes in behavior impacted by technology, vocational students' learning materials can be integrated with ICT, like electronic material or e-learning based materials. These materials are newly developed materials appropriate to the students' needs, which will be developed in a book integrated with technology. Therefore, besides having specific learning materials suitable for their needs, students will also be attracted by the integration of e-learning during the learning process. It is expected that students will have suitable materials based on their expertise program to be competent as a 
preparation to face the real work field after graduating from the school in the global context.

As mentioned in the situations above, the study is interested in three main objectives: (1) finding out the needs of the vocational school Nursing assistant students, (2) designing suitable materials to support teaching and learning activities for Nursing assistant students, and (3) evaluating the e-learning products' quality that had been developed. It is expected that the developed product may fill the gap in the context being studied. The Nursing assistant students will be provided with more suitable materials relevant to the work in the future.

\section{METHOD}

The methodology section comprises main sections of study design, instruments, data collection method, and data analysis. This study was designed in the research and development (R\&D), following Lee and Owens's R\&D Model (2004). The model focuses on developing multimedia-based materials. It consists of five steps, namely need analysis, design, development, implementation, and evaluation. Figure 1 presents the R\&D Model used in this study.

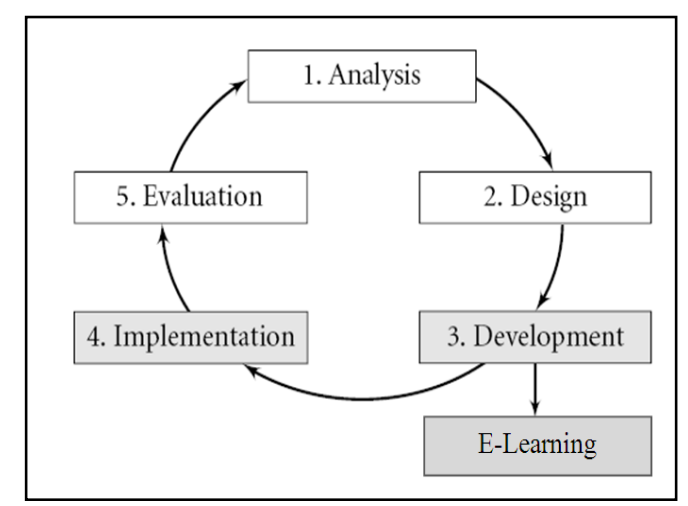

Figure 1. R\&D Model (adapted from Lee \& Owens, 2004, p. 3)

However, the study focused on the first three steps of the model, namely need analysis, design, and development due to limitation of time, budget, and space. The needs analysis stage was utilized using document analyses and interviews with English teachers, productive subject teachers, stakeholders, or practitioners in the Nursing field. The design stage was aimed at developing relevant topics that emerged from the results of the needs analysis. The design followed the content standards and suited to the existing syllabus and materials.

The writer developed a blueprint focused on selecting themes, skills, language function, language expressions, vocabularies, and other related language skills and components. The selection of an appropriate learning management system was also done in this stage. In the development stage, the revised blueprint was then developed into English for Nursing Assistant Materials. Another expert judgment process was conducted to check the quality of the materials and the quality of the elearning-based materials. Figure 2 elaborates on the research stages.

This study's data were collected through observation, interview, document analysis, and expert judgment sheet. The first three data collected during the need analysis process were analyzed using Interactive Model Analysis (Miles \& Huberman, 1994), while the expert judgment data were analyzed using Inter-rater Agreement Model (Gregory, 2000) and Mean Score Analysis (Candiasa, 2010).

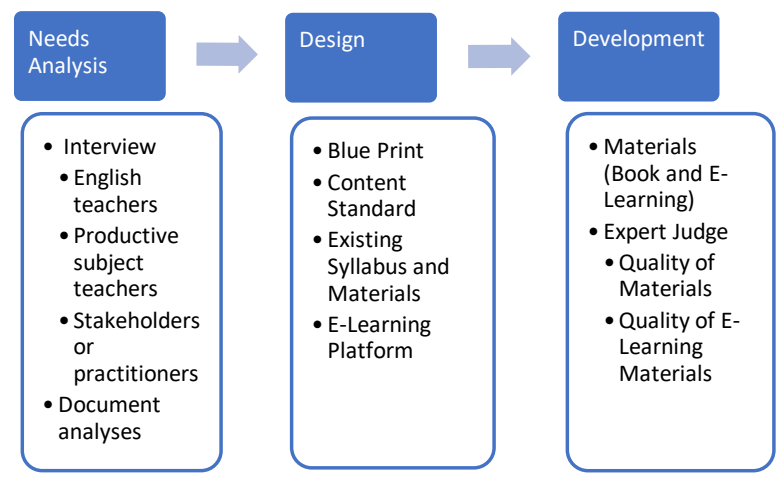

Figure 2. Flow Chart of the Study (adapted from Lee \& Owens, 2004) 
The interactive model consisted of four activities: data collection, data reduction, data display, and data conclusion (see Figure 3). The data were collected using interviews and observation, then transcribed and coded to be displayed. During these processes, some reductions took place when unnecessary data were present. At the final stage, all displayed data were verified or concluded to answer the research question.

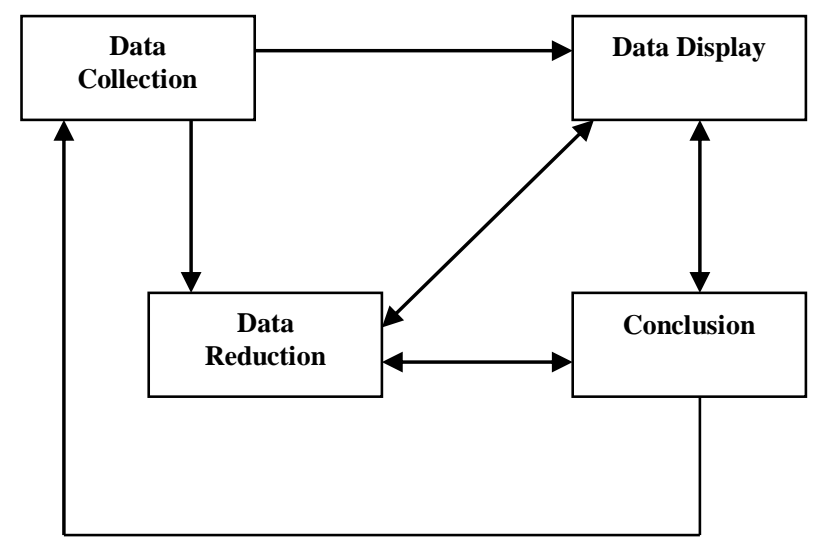

Figure 3. Interactive Data Analysis Process (Miles \& Huberman, 1994)

The inter-rater agreement model was utilized to analyze expert judgment results during the development of e-learning materials. This method is to find the content validity of the developed e-learning based English materials (Gregory, 2000). This analysis method involved three experts in the related area to evaluate the product based on the prepared expert judgment sheet. The Inter-rater agreement model was used in the content validity based on good ESP materials in the development stage. Table 1 presents the content validity agreement.

Table 1. Content Validity Agreement

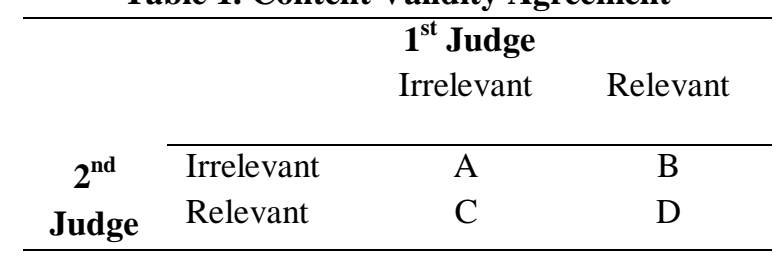

Note:

A: Disagreement between examiners (-,-)

B: Different agreement between examiners (+,-)

C: Different agreement between examiners $(-.+)$

D: Agreement between examiners $(+,+)$

All the judges' results were calculated using the following formula.

$$
\text { Content Validity }=\frac{D}{A+B+C+D}
$$

\section{Formula 1. Content Validity}

The formula shows that the content validity can be counted by the divided amount in column D. The result is valid if the calculated score is 1.0.

After the quality check on the ESP materials was conducted, the experts also judged the developed e-learning based English materials' quality. The data were analyzed using the criteria proposed by Candiasa (2010).

Table 2. Formula Scoring Adopted from Candiasa

(2010)

\begin{tabular}{ll}
\hline Interval Score & \multicolumn{1}{c}{ Criteria } \\
\hline $\mathrm{X} \geq \mathrm{M}+1.8 \mathrm{SD}$ & Excellent Material \\
$\mathrm{M}+1.8 \mathrm{SD}>\mathrm{X} \geq \mathrm{M}+$ & Good material \\
$0.6 \mathrm{SD}$ & \\
$\mathrm{M}+0.6 \mathrm{SD}>\mathrm{X} \geq \mathrm{M}-$ & Average material \\
$0.6 \mathrm{SD}$ & \\
$\mathrm{M}-0.6 \mathrm{SD}>\mathrm{X} \geq \mathrm{M}-1.8$ & Below average material \\
$\mathrm{SD}$ & \\
$\mathrm{X}<\mathrm{M}-1.8 \mathrm{SD}$ & Poor material \\
\hline
\end{tabular}

Note:

$\mathrm{X}$ : mean score

$\mathrm{M}=1 / 2$ (score $\max +$ score $\min )$

$\mathrm{SD}=1 / 3(M)$

All data analyses were expected to provide meanings to the data collected and to the process of e-learning material development. 


\section{RESULTS AND DISCUSSION}

As mentioned previously, the study aimed at three main purposes, namely finding out the needs of the English for Nursing Assistant instruction, designing relevant topics to support English for Nursing Assistant instruction, and developing e-learning based English for Nursing Assistant materials.

In developing the e-learning materials, need analyses were conducted using interviews, syllabi analysis, and existing English materials analysis. Based on the result of need analysis, there were several important highlights found, namely (1) Nursing assistant department students should have better communication skill to communicate with the guests or customers, (2) Nursing assistant department students should master the terms that are used in the Nursing area, (3) Nursing assistant department students should master some basic skills in the area, involving doing general checking, dealing with patients, checking vital signs, and hygiene.

The needs analysis showed a significant gap between the Nursing assistant students' future workplace needs and what they received during the study. It proved that the students' materials ran differently with the students' needs for their future workplace. General English was still used for learning, which was not suitable for the vocational school. Thus, the students should have specific materials that were related to the chosen major. The need analysis results helped the selection of related themes and topics needed to be developed to assist Nursing assistant students' learning.

After need analysis was conducted, the next procedure was designing the English materials. These were aligned with the previous analysis result to suit Nursing assistant students' needs that should be achieved for the future career. In this study, the developed product was supplementary and created for vocational school students with the integration of elearning. Based on the need analysis, there are five main topics urgently needed for the Nursing assistant students, namely General Assessment, Handling Patients, Patient's Hygiene, Checking Vital Sign, and Dimensions of Symptom. Table 3 presents the development plan for the topics.

Table 3. Topics for English for Nursing Assistant

\begin{tabular}{|c|c|c|}
\hline No. & Theme & Learning Objectives \\
\hline 1. & $\begin{array}{l}\text { General } \\
\text { Assessment }\end{array}$ & $\begin{array}{l}\text { - Use expressions to collect demographic data elements of patients } \\
\text { - Use expressions to collect current and past illness data of patients }\end{array}$ \\
\hline 2. & Handling Patient & $\begin{array}{l}\text { - Introducing self to the patients } \\
\text { - Asking the basic question to the patients } \\
\text { - Use expressions to offering service to the patients } \\
\text { - Use expressions to encourage/motivate patients }\end{array}$ \\
\hline 3. & Hygiene & $\begin{array}{l}\text { - Know the importance of bed making } \\
\text { - Identifying different types of bed at the hospital } \\
\text { - } \quad \text { Understand the importance of skin's care }\end{array}$ \\
\hline 4. & $\begin{array}{l}\text { Checking Vital } \\
\text { Sign }\end{array}$ & $\begin{array}{l}\text { - Use expressions to communicate with a patient when checking the vital sign } \\
\text { - Give some instructions during the implementation of checking the vital sign }\end{array}$ \\
\hline 5. & Symptom & $\begin{array}{l}\text { - Give communicative response to patient's complaint } \\
\text { - Ask the dimensions of symptoms }\end{array}$ \\
\hline
\end{tabular}

Each topic was developed in an integrated fashion by incorporating all language skills, like Speaking, Listening, Reading, and Writing and

\author{
language components, like Vocabulary, \\ Grammar, Pronunciation, etc.
}

The e-learning materials and activities were developed by using the Canvas platform. 
It was expected to ease students' learning in the digital era. The proposed topics were developed in the blueprint of materials and judged to know whether they are relevant. In designing the product, the consideration of good teaching material was required.

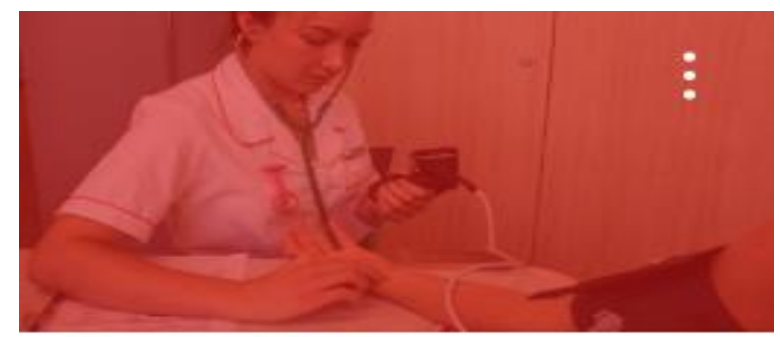

Checking Vital Sign

Unit 4
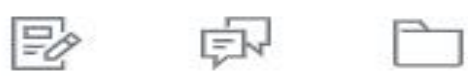

Figure 4. A Sample of E-Learning-based Materials for Nursing Assistant

The teaching materials should involve several criteria for good teaching material. Following Howard and Major (2005), there are criteria to make a good teaching material in this product, namely the material should be contextualized. In line with the curriculum and syllabus, the language teaching materials should be authentic, reflecting the language's use in real contexts. Language teaching materials should be attractive, and the materials should have appropriate or clear instruction.

After designing the topics, a further check on the ESP and e-learning materials' quality were conducted by the expert judgment procedure. There are three experts (two lecturers and one teacher in the area of Nursing) who contributed to the expert judgment. All expert judges were given a rubric developed based on the criteria of good ESP material proposed by Widodo and Savova (2010) and the criteria of good e-learning proposed by Bitter and Legacy (2009).
Table 5. Result on Good ESP Material

\begin{tabular}{cccccc}
\hline \multirow{2}{*}{ First Judge } & $\begin{array}{l}\text { Second } \\
\text { Judge }\end{array}$ & \multicolumn{3}{c}{ Third Judge } \\
\hline Item & Score & Item & Score & Item & Score \\
\hline 1 & 5 & 1 & 5 & 1 & 5 \\
2 & 5 & 2 & 5 & 2 & 5 \\
3 & 5 & 3 & 5 & 3 & 5 \\
4 & 5 & 4 & 5 & 4 & 5 \\
5 & 5 & 5 & 5 & 5 & 5 \\
6 & 5 & 6 & 5 & 6 & 5 \\
7 & 5 & 7 & 5 & 7 & 5 \\
8 & 5 & 8 & 5 & 8 & 5 \\
9 & 5 & 9 & 5 & 9 & 5 \\
10 & 5 & 10 & 5 & 10 & 5 \\
\hline Total & $\mathbf{5 0}$ & Total & $\mathbf{5 0}$ & Total & $\mathbf{5 0}$ \\
\hline
\end{tabular}

It was found from Table 5 that the mean score of all expert judgment is 50 , thus $\mathrm{X}=50$.

$\mathrm{M}=1 / 2($ Score $\max +$ Score $\min )$

$\mathrm{M}=1 / 2(50+10)$

$\mathrm{M}=30$

$\mathrm{SD}=1 / 3(M I)$

$\mathrm{SD}=1 / 3(30)$

$\mathrm{SD}=10$

Therefore, the result of $\mathrm{M}$ and SD were put into the formula.

$\mathrm{X} \geq \mathrm{M}+1.8 \mathrm{SD}$

$50 \geq 30+1.8(10)$

$50 \geq 48$

The result means that the developed materials were categorized as excellent ESP material. A further quality check was also conducted for elearning materials being developed. By using the same formula, the results of expert judgments are presented in Table 6 .

Table 6. Result on Good E-learning Product

\begin{tabular}{cccccc}
\hline \multicolumn{2}{l}{ First Judge } & \multicolumn{2}{c}{ Second Judge } & \multicolumn{2}{c}{ Third Judge } \\
\hline Item & Score & Item & Score & Item & Score \\
\hline 1 & 5 & 1 & 5 & 1 & 5 \\
2 & 4 & 2 & 4 & 2 & 5 \\
3 & 5 & 3 & 5 & 3 & 5 \\
\hline
\end{tabular}




\begin{tabular}{cccccc}
\hline 4 & 5 & 4 & 5 & 4 & 5 \\
5 & 5 & 5 & 5 & 5 & 5 \\
6 & 5 & 6 & 5 & 6 & 5 \\
7 & 5 & 7 & 5 & 7 & 5 \\
8 & 5 & 8 & 5 & 8 & 5 \\
9 & 5 & 9 & 5 & 9 & 5 \\
10 & 5 & 10 & 5 & 10 & 5 \\
\hline Total & $\mathbf{4 9}$ & Total & $\mathbf{4 9}$ & Total & $\mathbf{5 0}$ \\
\hline
\end{tabular}

Table 6 shows that the mean score of all expert judgment is 49 , thus $X=49$.

$\mathrm{M}=1 / 2$ (Score $\max +$ Score $\min )$

$\mathrm{M}=1 / 2(50+10)$

$\mathrm{M}=30$

$\mathrm{SD}=1 / 3(M I)$

$\mathrm{SD}=1 / 3(30)$

$\mathrm{SD}=10$

The result of $\mathrm{M}$ and SD were then put into the formula.

$\mathrm{X} \geq \mathrm{M}+1.8 \mathrm{SD}$

$49 \geq 30+1.8(10)$

$49 \geq 48$

The result of the calculation from all expert judges is $49 \geq 48$. It means that the English for Nursing assistant learning materials supplemented by E-learning can be considered excellent material. Therefore, the developed materials were checked, and the results found that they are excellent.

Based on the need analysis that has been done by the researcher, there were some main jobs of nurse assistants. They are checking vital signs (checking blood pressure and checking body temperature), bed making, hair care, oral care, oral medicine, administration, making notes, and making notes of symptoms. After the need analysis, it was found that there is a gap between the required abilities in the workplace and the materials being taught in the vocational school. In the student's textbook, there were no specific English materials as what was found in the need analysis. The contents of the book were primarily focused on general English. Apart from the technical skills needed for a Nursing assistant, students were also expected to communicate well in English while mastering some basic terms in the area.

The design of the material was based on the need analysis. It was the guidance in developing the English learning materials for the students. According to Howard and Major (2005), teaching materials play a crucial role in most English teaching programs. Thus, in this case, developing English materials are considered important. Concerning this research, e-learning based English for Nursing assistant materials was developed. It could be categorized as ESP materials which allow students to learn appropriately based on their needs and interest. Hutchinson and Waters (1987) state that learners have different needs and interests that will influence their motivation to learn and make their learning more effective. Students were more focused on their major to reach their goals in the future. Through this English material, students are expected to learn more specifically in their area of interest. Bilokcuoğlu (2012) points out that this kind of material is normally 'goal-directed,' meaning that ESP material will direct the students to reach their goal in learning English.

There were five units developed in this study; those are General Assessment, Handling Patients, Hygiene, Checking Vital Sign, and Symptom. Further, the students achieved several learning outcomes, which should be achieved by the students by carrying out the activities designed in each topic. The English learning materials supplemented by e-learning were designed for practicing the four language skills, namely reading, writing, listening, and speaking. According to Tomlinson (2012), good learning materials should have the students to develop their confidence. Therefore, the activity for practicing students' speaking skill was designed. The students mostly required making dialog conversation because when they did a 
dialog conversation, they need to express themselves using the language they had learned confidently. Further, vocabulary activities were also designed to improve the students' knowledge of unfamiliar words related to their future job. Rohmah (2015) has developed similar English materials for the ESP context. $\mathrm{He}$ found that a more specific material may increase students' abilities and direct their interest more.

The materials were developed in an elearning fashion using Canvas. It is a kind of Learning Management System (LMS) that provides online interaction between teacher and students. According to Adzharuddin and Ling (2013), LMS is a portal that enables teachers and students to interact outside the classroom, having online discussions through forums that could otherwise take up too much of the time supposed to be spent in the classroom learning interaction. Based on its official website, Canvas is defined as a cloud-based LMS that makes teaching and learning easier. That tool is designed to be used online, on mobile, and a tablet. Some audios in the listening exercise were uploaded to Canvas. There were some listening exercises provided in the book. Thus the students should listen to audio provided on the website, and there was also some homework on the website that the students should submit.

The quality of the English learning materials integrated with E-learning was also evaluated through expert judgment. Three experts contributed to the expert judgment, two are lecturers, and one is a teacher in the area. It was found that all judges had responded to the rubrics provided on the quality of ESP materials and the quality of e-learning-based materials. The expert judgment rubrics were developed based on the criteria of good ESP material proposed by Widodo and Savova (2010) (2010) and the criteria of good e-learning by Bitter and Legacy (2009). All expert judges' calculation results show that the developed materials are in the "Excellent" category. This is in line with what Tomlinson (2012) highlights: A good quality e-learning material will potentially help students develop more effective learning.

\section{CONCLUSION}

This study is a research and development (R\&D) aimed at developing English for Nursing assistant learning materials aided by elearning. This study was conducted to determine the needs of the students, teachers, and stakeholders of the Nursing area, design English for Nursing assistant learning materials aided by e-learning, and check the quality of the developed materials in terms of good ESP and good e-learning materials. The study found out that more relevant materials are needed by the teaching and learning process. Important topics, like general assessment, handling patients, hygiene, vital signs, and symptoms, were developed in the new materials as they were not included in the existing materials. Rich activities in different foci of skills are developed with various exercises, in-class meetings, and lengthened e-learning-based practices. The quality check of the materials shows that it is excellent and, therefore, used in the teaching and learning process. It is suggested that the school could use the developed materials to teach the students, especially as supplementary English materials. As the material was also online, the teacher could give the students a new experience in learning.

\section{REFERENCES}

Adzharuddin, N. A., \& Ling, L. H. (2013). Learning Management System (LMS) among University Students: Does It Work? International Journal of E-Education, eBusiness, e-Management and e-Learning, 3(3), https://doi.org/10.7763/ijeeee.2013.v3.233

Alismail, H. A., \& McGuire, P. (2015). 21st 
century standards and curriculum: Current research and practice. Journal of Education and Practice, 6(6), 150-155.

Badan Nasional Standar Pendidikan (BNSP). (2006). Standar kompetensi dasar SMK/MAK.

Bilokcuoğlu, H. (2012). English for specific purposes: "A paper on the special area of English of the non-specialist ESP English instructor." EUL Journal of Social Science, 3(1), 78-91.

Bitter, G. G., \& Legacy, J. M. (2009). Using technology in the classroom. Pearson/Allyn and Bacon.

Candiasa, I. M. (2010). Pengujian instrumen penelitian disertai aplikasi ITEMAN dan BIGSTEPS. Unit Penerbitan Universits Pendidikan Ganesha.

Condruz-bacescu, M. (2014). E-Learning/MLearning: The new trend in foreign language teaching. Professional Communication and Translation Studies, 7(1-2), 159-166.

Education First. (2020). EF English proficiency index: A ranking of 100 countries and regions by English skills. Education First. https://www.ef.sg/epi/

Gregory, R. J. (2000). Psychological testing: History, principles, and applications. Pearson Education Limited.

Howard, J., \& Major, J. (2005). Guidelines for designing effective English language teaching materials. In K. O. G. Gakkai (Ed.), Proceedings of the 9th Conference of Pan-Pacific Association of Applied Linguistics (Vol. 9, pp. 101-109). Waseda University Media Mix Corp.

Hutchinson, T., \& Waters, A. (1987). English for specific purposes: A learning-centred approach. Cambridge University Press.

Kivunja, C. (2015). Teaching students to learn and to work well with 21 st century skills: Unpacking the career and life skills domain of the new learning paradigm. International Journal of Higher Education, 4(1), 1-11.

Lee, W. W., \& Owens, D. L. (2004). Multimedia-based Instructional Design (2nd ed.). Pfeiffer.

Lowerison, G., Sclater, J., Schmid, R. F., \& Abrami, P. C. (2006). Student perceived effectiveness of computer technology use in post-secondary classrooms. Computers and Education, 47(4), 465-489. https://doi.org/10.1016/j.compedu.2004.10 .014

Miles, M. B., \& Huberman, A. M. (1994). Qualitative data analysis: An expanded sourcebook (2nd ed.). Sage Publications, Inc.

Rohmah, C. (2015). Developing English learning materials for eleventh grade students of marketing study program at SMK Muhammadiyah 2 Bantul [Universitas Negeri Yogyakarta]. eprints.uny.ac.id/26670/1/skripsi.pdf

Santosa, M. H. (2019). Introduction to Core Skills and its best practices in the Indonesian classrooms. In M. H. Santosa (Ed.), Penerapan Core Skills di kelas-kelas di Indonesia (1st ed., Vol. 1, pp. 07-23). Azizah Publishing.

Tomlinson, B. (2012). Materials development for language learning and teaching. Language Teaching, 45(2), 143-179. https://doi.org/10.1017/S02614448110005 28 
Umezaki, S. (2012). Building the ASEAN Economic Community: Challenges and opportunities for Myanmar. In H. Lim \& Y. Yamada (Eds.), Economic Reforms in Myanmar: Pathways and Prospects (p. 35). Bangkok Research Center, IDEJETRO.

Vanve, A., Gaikwad, R., \& Shelar, K. (2016). A new trend e-larning in education system. International Research Journal of Engineering and Technology, 3(4), 299302.

Widodo, H. P., \& Savova, L. (2010). The Lincom guide to ELT materials design and development: Theory and practice. Lincolm Europa. 